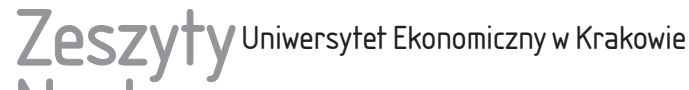 Naukowe
}

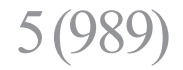

ISSN 1898-6447

e-ISSN 2545-3238

Zesz. Nauk. UEK, 2020; 5 (989): 7-30

https://doi.org/10.15678/ZNUEK.2020.0989.0501

Nazar Podolchak

Olena Bilyk

Mariia Khim

\section{Digitalisation of the Economy as a Factor in Increasing State Competitiveness}

\begin{abstract}
Objective: The article considers the main challenges and benefits of digitalisation of Ukraine's economy, outlines the threats and risks posed by this process, to develop tools and digital transformation plans for assessing the level of digital economy in Ukraine.

Research Design \& Methods: A retrospective analysis of the economic and social development of the states in question is conducted. It takes into account the implementation of digitalisation and use of medium-term budget planning. A ranking method is used to display the change in the rank of the states in 2019 vs 2009. It employs the following
\end{abstract}

Nazar Podolchak, Lviv Polytechnic National University, Administrative and Financial Management Department, 28a Stepan Bandera St., Lviv, Ukraine, e-mail: nazar.podolchak@gmail.com, ORCID: https://orcid.org/0000-0002-0284-9601.

Olena Bilyk, Lviv Polytechnic National University, Administrative and Financial Management Department, 28a Stepan Bandera St., Lviv, Ukraine, e-mail: olena.bilyk@gmail.com, ORCID: https://orcid.org/0000-0002-7110-7257.

Mariia Khim, Lviv Polytechnic National University, Administrative and Financial Management Department, 28a Stepan Bandera St., Lviv, Ukraine, e-mail: missm28@ukr.net, ORCID: https:// orcid.org/0000-0002-3151-6435.

This is an open access article distributed under the terms of the Creative Commons Attribution-NonCommercial-NoDerivatives 4.0 License (CC BY-NC-ND 4.0); https://creativecommons.org/ licenses/by-nc-nd/4.0/ 
indicators: gross domestic product at current prices, gross domestic product per capita at current prices, unemployment, national income, total expenditure of public administration, and the network readiness index.

Findings: The research makes it possible to draw conclusions about the need to create conditions for digitalisation in Ukraine. The ability to use digital resources has proven effective during the COVID-19 pandemic. More generally, we assessed the macroeconomic effect by assessing the impact of investment in digital technologies and digital infrastructure on GDP, as well as by assessing productivity growth through digitalisation. According to the estimates cited in this article, the share of the digital economy in the GDP of the world's largest countries in 2030 will reach 50-60\%. In Ukraine, the figure may run even higher, to $65 \%$ of GDP (in the implementation of the forced scenario of the digital economy in Ukraine).

Implications /Recommendations: Based on the conducted research, two scenarios for the development of digitalisation in Ukraine are put forward: 1) accelerated digitalisation and 2) gradual digitalisation. If scenario 2 is implemented, Ukraine's economy will remain inefficient, labour migration and brain drain will continue, and Ukrainian products will become less competitive in foreign markets. Ukraine will remain in the backyard of civilisation. Scenario 1 envisages the transition of the Ukrainian economy to a digital one in 3-5 years. Under the implementation of the forced scenario, by 2030 Ukraine will become a European leader in innovation and new technologies, and an intellectual hub.

Contribution: The research conducted by the authors will allow to establish the main directions of development of the digitalisation of Ukraine's economy on the basis of European experience, while the proposed development scenarios will help to create the most attractive conditions in the region for the development of human potential.

Keywords: digital economy, digitalisation, digital services, digital technologies, information and communication technologies, state, society.

JEL Classification: C10, F29, 010, O33, O40, O57.

\section{Introduction}

Nowadays Ukraine is struggling to achieve economic and social development. As socio-economic reforms are implemented, there is a need to rethink the meaning of public welfare itself. A system of effective control over the dynamics of population welfare indicators that would take into account the digitalisation of the economy has yet to be created. Market relations radically change the conditions of reproduction and the human factor, methods of management and the regulation of employment, all affect the development of the education system and solutions to how to feed the country's population. The complexity of processes involved in transitioning to market relations makes it necessary to study the self-regulation of the economy, ways to achieve a balanced distribution and redistribution of income in modern conditions. 
Today, the digital transformation of the economy is associated with both high expectations (economic growth, improved services, greater competitiveness, to name three) and fears (job cuts, rising inequality, growing threats to information security). Many countries have developed digital strategies and action plans for increasing the opportunities offered by third-wave digital technologies, such as artificial intelligence (AI), the analysis and storage of big data, distributed ledger technology, and the Internet of Things (IoT). They have also developed programmes for managing the risks associated with digital transformation. In these conditions, developing adequate information and analytical support for the management of digital transformation processes at the national, regional and sectoral levels, as well as the creation of the necessary tools for doing so, becomes urgent.

This article presents the main challenges and benefits of the digitalisation of Ukraine's economy and outlines the threats and risks posed by this process, to develop tools for assessing the country's level of economic digitalisation.

The state of economic innovation is adequately reflected by indicators characterising the prevalence of innovation among enterprises, as well as the activity of the population in launching businesses and their innovation. This study is intended to fill gaps in the research applying to these areas.

In connection with the above, the topic, purpose and objectives of the study are extremely well-founded and timely, as a number of Ukrainian authors have written. An important aspect is that there is a covariance relationship between economic development and public welfare. All of this lends the topic significant theoretical and practical value.

The purpose of the article is to consider the main challenges and benefits of digitalising Ukraine's economy. It also outlines the threats and risks posed by this process, and proposes tools and digital transformation plans for assessing the extent to which Ukraine's economy has been digitalised.

\section{Analysis of Recent Research and Publications}

Digitalisation in Ukraine is unfortunately developing at a much slower pace than in developed countries. The author S. Korol has said that "the formation of the digital economy in Ukraine should become a driving force for increasing GDP and improving living standards. Using digital technology, each sector of the economy can grow faster, better and more efficient. This inspires widescale interest among scientists in the concept of digital economy and digitalisation" (Korol 2019, p. 68).

Obstacles to digitalising the economy and its influence on the country's competitiveness have been investigated by Ukrainain and foreign researchers. The group includes: H. Ansoff (Ansoff 1998, Ansoff \& McDonnell 1990), R. Ackoff (1974), S. Veretyuk (Veretyuk \& Pilinskiy 2016, pp. 51-58), S. Voitko (2019), A. Glush- 
chenkova (Glushchenko \& Kucherova 2016), P. Gudz (Gudz \& Gudz 2019), P. Drucker (2002), I. Zelisko (2012, pp. 264-270), N. Kraus (Kraus \& Kraus 2018, pp. 211-214), R. Lipsey (Lipsey \& Chrystal 2015), P. Stetsyuk (Sergienko et al. 2009, pp. 187-203), A. Toffler (1980), K. Schwab (2016), E. Laitsou, A. Kargas and D. Varoutas (2020), S. Nagy (2017, pp. 174-179) and others.

S. Nagy first analysed the state of the digital economy and society in Hungary, compared it with Ukraine and drew conclusions about future development trends. Using secondary data provided by the European Commission, he examined the five components of the Digital Economy and Society Index of Hungary, conducted an analysis to identify significant differences between Ukraine and Hungary in terms of Internet access and the use of devices including smartphones and computers. E. Laitsou examines the serious problems Greece faces due to low levels of digitalisation, both on the demand side (businesses that consume Internet services) and on the supply side (institutional and government constraints).

At the same time, the impact of digitalisation on socio-economic relations, the identification of opportunities and justification of measures to build qualitatively new management models based on modern digital technologies needs further research. In this article we explore the level of digitalisation of most European countries, build specific scenarios for development and make recommendations to improve the situation.

\section{Materials and Methods}

Available state data were used and innovative approaches applied, allowing us to carry out a retrospective analysis of the economic and social development of the countries, taking into account the implementation of digitalisation and using medium-term budget planning. For this we use a ranking method and explore the countries' change in rank in 2019 vs 2009 according to the following indicators: gross domestic product at current prices, gross domestic product per capita at current prices, unemployment, national income, total expenditure of public administration, and the Network Readiness Index (NRI).

\section{Research of the Main Aspects of Digitalisation of Economy and Construction of Scenarios of Its Development in the European Countries}

State philosophy maintains that man has a social nature, and people can achieve self-realisation only through the community. Common goals and values 
establish communities and identification with the state. Since the common good depends on value systems, it also combines ideological elements.

The common good means the good as a whole and concerns the common interests of the community, society and global community. It implies a consensus on goals, means and ways. However, it is often overlooked that societies across the globe demonstrate diverse interests, values and goals. Against the background of economic globalisation and changes in economic structure and values, the concept of "the common good" increasingly requires expansion, and the social market economy and market mechanisms lack the ability to sufficiently serve the common good. Therefore, civil society needs strengthening: members of society must increasingly reach out to each other and take joint responsibility for participation. Putting aside the large number of companies - small, medium-sized and large one alike - that are committed to society as a part of ensuring "corporate social responsibility", it remains incumbent upon the business community to further promote the common good.

Non-governmental intermediate organisations are also working toward the common good. The community and its voluntary participation are increasingly promoted at the local level. In the end, the financial crisis of the welfare state also led to the rethinking of social policy, which redefined the principle of subsidiarity. In addition to the revival of associations, which largely dominate the socio-political space, the concepts of self-help, known since the post-war period, and development assistance are increasingly used and are based on existing (civil) initiatives and associations. The fair distribution of income is a subject of economic theory, particularly the concept of public welfare, an important theme of Adam Smith's work (Gray 1948). Smith formulated the dependence of public welfare on the quantity of the annual product of labour and the number of consumers, as well as on the correspondence of the consumption of the annual product to the needs of consumers met.

Marx's theory of reproduction concerns the reproduction of capital and economic growth in all types of production. On the basis of his theories of value and value-added, Marx first developed a scientific theory of social reproduction. His analysis of capitalist reproduction process records the relations and interrelations of many competing individual capitals related to the use and value of the economy in the process of reproduction. Marx demonstrates the capitalist character and antagonistic contradictions of this particular historical form of social reproduction (Burawoy 1990, pp. 775-793).

Walras was a Swiss economist who developed a theoretical model of general economic equilibrium in the classical market. His theory on welfare is intertwined with questions of economic balance. Based on the analysis of supply and demand, his model consists of several systems of equations. The leading position 
is occupied by a system that characterises the balance of two markets - productive services and consumer goods. The economist assumes that the supply of labour resources is equal to their demand; that is, he admits the possibility of zero unemployment. The unemployed are those subjects who estimate the usefulness of free time to be greater than the usefulness of monetary income received as a result of work. If in such a market the supply of labour exceeds demand, then wages decrease, hence employment loses its attractiveness; the supply of labour falls and, as a result, equilibrium is restored (this is called equilibrium unemployment) (Voronin \& Kizim 2006, pp. 71-74).

Social welfare consists of five social dimensions:

- social perception,

- social actualisation,

- social contribution,

- social consistency,

- social integration.

However, economic characteristics are also an important aspect of ensuring social welfare. In other words, to maximise welfare, it is necessary to create conditions for economic equilibrium, which, in turn, depends on the high economic culture of consumers and producers, their ability to participate in price competition and focus on maximising utility. It should therefore come as no surprise that issues of equilibrium have now been addressed by numerous generations of economists. Public welfare is an economic relationship regarding the formation of national income, its equitable distribution, redistribution and use; it is a set of socially normal conditions necessary for the amplified social reproduction of each individual in society as a requirement of scientific and technological progress.

The development of the digital transformation of the economy is today saddled with both considerable expectations (economic growth, higher-quality services, enhanced competitiveness) and worries (job cuts, increased inequality and larger threats to information security). Many countries have developed digital strategies and action plans intended to develop opportunities offered by third-wave digital technologies - such as artificial intelligence, analysis and the storage of big data, distributed ledger technology or the Internet of Things - and the management of risks associated with digital transformation. In these conditions, providing adequate information and analytical support for the management of digital transformation processes at the national, regional and sectoral levels, and creating the necessary tools for this to happen have become urgent tasks.

The global impact of information resources and information and communication technologies on the entire socio-economic space, the high speed of their distribution, the wide opportunities for their use in various areas of social and industrial activities and the scale of informatisation processes oblige us to measure 
the impact of information shifts and the use of information and communication technologies on social development based on statistical methods, taking into account medium-term budget planning.

The global information technology market's growth rate is outpacing that of traditional industries (Veerpalu et al. 2014, pp. 12-16), while the two markets are comparable in terms of absolute value. International practice today uses the development index of information and communication technologies (ICT) when analysing the digitalisation of the economy. The ICT development index consists of three subindexes: ICT accessibility (IDI access subindex), ICT use efficiency (IDI use subindex), and the population's ability to use the ICT (IDI skills subindex) (International Telecommunication Union 2017).

An important research question concerns the development of a model of the state's social and economic development in terms of medium-term budget planning. The efficiency of the economy in general, including the sustention of a moderate level of social inequality, creates the necessary general conditions for the country to implement the latest ICTs. Healthy competition in the economy is necessary for the formation of an economic environment that encourages the introduction of new technologies, research and development.

The effectiveness and quality of all these and other institutional elements of the national economic system open up opportunities for the realisation of the population's entrepreneurial potential, particularly in digital technologies and their use for innovative business models.

Because digitalisation processes affect almost all areas of economic activity, macroeconomic indicators can reflect the nature of changes. The conceptual basis for quantifying the state of the innovation climate in national economies is formed on the assumption that the following categories of parameters have the greatest impact on the comfort of innovation activities. We have generalised these categories based on the works of Ukrainian researchers including A. Trushlyakova (2018, pp. 186-191), N. Azmuk (2014), K. Kovtonyuk (2017), and M. Kulynych (2019, pp. 57-63):

1) gross domestic product (GDP) is the main generalising indicator of a country's economic development. It reflects the total volume goods and services produces over a certain period. GDP characterises economic activity in a country and determines its place in the world. Calculating GDP makes it possible to assess the results of production and consumption, economic growth rates, and labour productivity, as well as to form an idea of the nation's overall welfare (State Statistics Service of Ukraine 2019);

2) GDP per capita (the value of GDP divided by the number of inhabitants) gauges the level of economic activity and the standard of living of a country's or region's population over a certain period. Indicating the country's or region's level 
and dynamics of economic growth and development, GDP per capita shows only the average value, but does not capture inequality of income or the population's welfare;

3) employment and unemployment. The employment rate is a relative indicator of employment among adults. It is calculated as the ratio of the employed population to the total population aged 15 to 70 . The unemployment rate is a relative indicator of unemployment, showing its prevalence among the economically active population. It is calculated as the ratio of the number of unemployed people to the number of economically active people. The analysis of economic indicators makes it possible to estimate losses from underutilisation of labour resources due to unemployment. A decrease in population categories such as the number of economically active and employed people (as well as the levels of economic activity and employment) causes labour resources to decrease, which is an undesirable trend for the country's economy. A decrease in the number of the unemployed and the unemployment rate causes the labour market to grow (International Labour Office 2018);

4) government expenditure (as a percentage of GDP) indicates the size of public administration in different countries. A large difference in expenditure rates indicates the diversity of approaches countries employ in providing public goods, services, and social protection, not necessarily the difference in resources spent. This figure is measured in thousands of dollars per capita and as a percentage of GDP. All OECD countries collect their data according to the 2008 System of National Accounts;

5) government revenue (as a percentage of GDP). Governments collect revenue primarily for two purposes: to finance the goods and services they provide to citizens and businesses, and to fulfill their redistributive role. Measuring the public sector's contribution to the economy in terms of available financial resources makes it possible to compare the levels of government revenue in different countries. The total amount of revenue collected by governments is determined by past and current political decisions. This figure is measured in thousands of dollars per capita and as a percentage of GDP.

To build scenarios for the development of digitalisation in Ukraine, the study used indicators of social development and digitalisation of such countries as Poland, Belarus, Romania, Germany, and Estonia. The main assumptions for the election of these countries were as follows:

1) Poland, Romania, and Belarus share a border with Ukraine,

2) Germany and Estonia are the reference countries,

3) Ukraine and the other countries share the influence of a historical factor, i.e., the influence of the command economy during the period when Ukraine was a part of the Soviet Union. 
The third assumption is based on the cultural theory of state development, which emphasises the state as a primarily cultural artifact and focuses on how symbolism plays a primary role in the formation of the state (Barkey \& Parikh 1991, pp. 523-549). Most strikingly, some studies highlight how the creation of national identification and citizenship were crucial to the formation of the state. In this context, the state is not just a military or economic authority: it also includes cultural components that create people's consent, rights and state affiliation (Alonso 2005, pp. 3-26).

Each of the countries we studied demonstrates a relatively small share of domestic research and development expenditures to GDP. This indicator determines the availability of financial resources for research activities. The low value is explained, in particular by a lack of interest among national business in developing new technologies.

The defining indicator in the context of building a digital economy is GDP per capita, which is several times lower in Ukraine than in the leading countries. While increasing Ukrainians' standard of living has been on the state authorities' agenda for many years, the state of economic development will not yet allow a leap to be taken.

The ratio of income and expenses indicates a state's competitiveness in the world and domestic markets. However, a sufficient level of maturity of the digital sector of the economy is not achievable without large local companies - suppliers of goods and services that can compete with external players, including global sector leaders.

The lack of positive social and economic effects is an extremely worrying indicator of the entire process of digital transformation. Of course, they may not be observed in the short term or they may be offset by other negative effects, but at the end of an extended time interval (for example, 3-5 years), their identification is critical for calibrating government regulation measures and adjusting a national development strategy.

Analysing this system of indicators, we see that according to all these indicators, Ukraine is not a country with a completely failed economy, but so far has no prospects of becoming an absolute leader. In general, Ukraine's business environment is characterised by a fairly uniform state of development, having rich growth reserves in almost all of the areas studied.

More and more information about aspects of modern economic life is being published on ratings characterising the development of individual countries and their place in the world economy. Country images in the global world are objectively assessed. International ratings are becoming an increasingly important source of information about the potential and development dynamics of certain countries. Research on a country's place on the global scale is relevant because 
ratings can indicate the need to implement measures to overcome shortcomings and create broad opportunities to increase competitive advantages.

Annually since 2002, the World Economic Forum (WEF), the World Bank (WB) and the INSEAD international business school have been calculating and publishing the Network Readiness Index (NRI) (Silja, Soumitra \& Bruno 2017). The NRI evaluates a country's ability to use ICT capabilities for network purposes. Firstly, the NRI provides information about the main factors that affect the development of the network economy, with a view to their consideration in public policy. Secondly, in the long term, this information engages more people, organisations and communities globally. The NRI not only evaluates a country's readiness to participate in the information space, but also shows why countries are different.

Network readiness depends on whether a country has the drivers needed to use digital technologies to reach their potential and whether these technologies actually affect the economy and society. The research breaks down that information into units to get an accurate picture of all drivers and the full effects. The NRI consists of four subindexes that assess the environment for IT development, society's readiness to use it, actual IT use by state, business, and population, and the consequences that IT has for the economy and society. The first three subindexes are growth drivers, and are also prerequisites for the fourth subindex, which evaluates the impact of IT on society and the economy. These four subindexes are divided into 10 parts and 53 variables. The first subindex - "environment" - includes such components as political and regulatory environment, business and innovation environment; the second subindex - "readiness" - covers infrastructure and digital content, the availability of IT, a population's skills; the third one - "use" - reveals the extent of use by individuals, business and government; and the fourth subindex - "influence" - is logically derived from the above subindexes and contains the following two components: the impact of IT on the economy and its impact on society in a particular country. The total value of the index is the arithmetic mean of the four subindexes listed (Breen 2016).

The Network Readiness Index was first published in 2002 and has provided an integral basis for assessing the multifaceted impact of ICT on the development of societies and nations alike. By 2016, the NRI was part of the Global Information Technology Report (GITR) published by the World Economic Forum (2009-2016), Cornell University, and INSEAD. Last published in 2016 by the World Economic Forum, first in collaboration with the World Bank, then with INSEAD, and later in partnership with both INSEAD and Cornell University, the NRI has been recognised as a global benchmark for assessing countries' progress and preparedness to adopt technology. Over the years, the NRI has identified the opportunities and challenges that governments, businesses, research teams and individuals face in 
striving to fully capture the benefits of technology and has provided valuable, data-based guidance for leaders of both the public and private sectors (Portulans Institute 2019c).

In 2019, undergoing internal reconstructions and changing priorities, the WEF handed over the production of NRI to its original editors - Soumitra Dutta and Bruno Lanvin. This provided an excellent opportunity to revise the structure of the NRI and make it more suitable for modern conditions - Figure 1 (Portulans Institute 2019a).

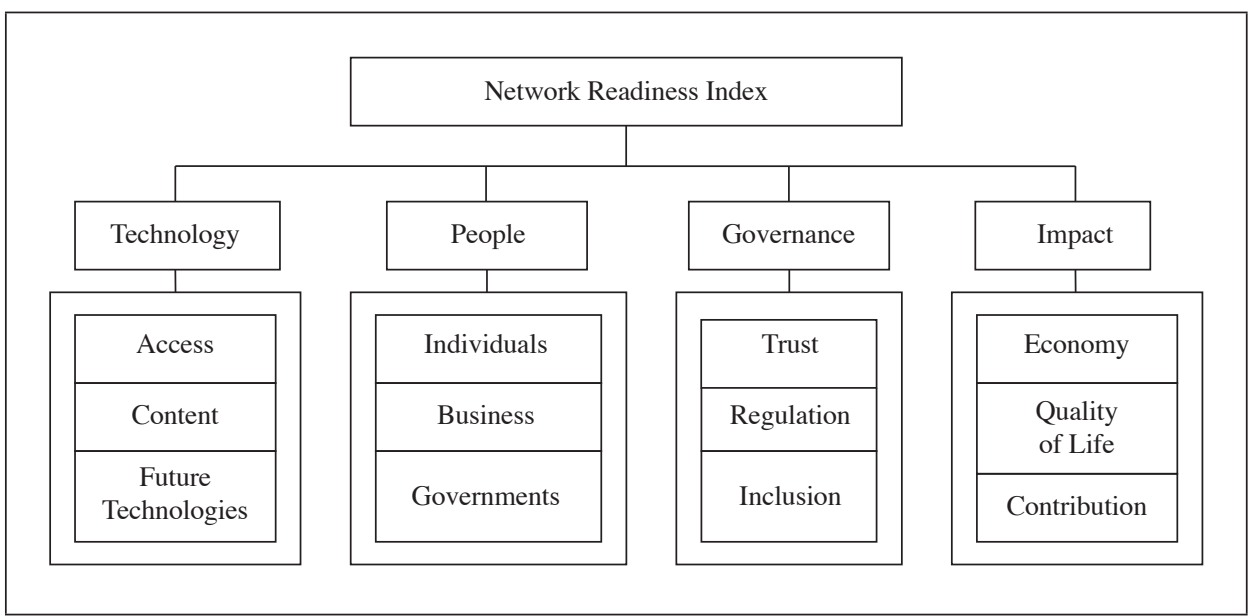

Fig. 1. The NRI Model of 2019

Source: (Portulans Institute 2019c).

A technical advisory group was then established to provide advice on how the NRI model should be redesigned. Three main goals guided the process (Portulans Institute 2019b):

- to maintain continuity with the main components of the NRI of previous years,

- to display current ICT implementation issues that were not adequately documented in the NRI model of 2016,

- to validate the new NRI model for future technological trends and developments.

The new method of calculating the NRI has had an improved structure since 2019, so it is not quite possible to compare the results of that year with the ratings of previous editions. However, the fundamental basis of the NRI remains unchanged, and the NRI rating of 2019 is similar in its results to the NRI of 2016.

In fact, eight of the top ten countries of this year made it to the top ten in the NRI of 2016. To better analyse Ukraine's network readiness, it should be compared with that of the other countries selected here for analysis. The analysis 
was conducted on the basis of the ratings for the years 2009-2019. Ranking is one of the methods of benchmarking.

The benchmarking methods described in this manual are an important step forward for the practice of regional economic development planning. Benchmarking results are extremely useful in the development of any strategic plan, informing it of the jurisdiction's strengths, which can be reinforced, and its relative weaknesses, which can be remedied through activities within the scope of the strategic plan. In the most general sense, a benchmark contains a certain quantity, quality and ability to be used as a standard or reference in comparison with other objects (processes or phenomena).

Sequential ranking in benchmarking means determining and assigning a serial number to each country for each indicator. For data processing, especially large arrays, it is advisable to use MS Excel functions (rank, order, etc.).

The method is based on an integrated and multidimensional approach, while the assessment is based on statistical reporting, is comparative, and takes into account the state of each country's development. Standard deviation is the most common measure because its characteristics meet the needs of aggregation. All variables are reduced to a single scale and a "normal" distribution is established. However, significant fluctuations in values can significantly affect the generalised indicator.

The minimum-maximum method normalises data in a range from 0 (worst) to 1 (best). It is similar to the $Z$-index method, but uses a variable scale of values for each indicator. As a result of this transformation, all normalised values have the same range from 0 to 1 . The "distance from the leader/standard" method is assigned a value of 100 , and all others are ranked according to the percentage points that separate them from the leader/standard. This method is based on determining the degree of proximity of the objects under study to the object that is the standard (Blishchuk, Krupnyk \& Matviishin 2014).

We have analysed the data collected for NRI purposes. The results of the analysis are shown in Table 1 . We will carry out a retrospective analysis of the economic and social development of six states (Belarus, Estonia, Germany, Poland, Romania and Ukraine), taking into account the implementation of digitalisation and using medium-term budget planning. For this we use a ranking method and display the change in the rank of the states in 2019 vs 2009 (Table 1 and 2) by selecting the following indicators: GDP at current prices, GDP per capita at current prices, unemployment, national income, total expenditure of public administration, and the network readiness index.

According to the indicators, in 2009 Ukraine ranked last among the countries selected for the study, while Germany was at the top. However, over the course of ten years, structural changes have taken place in the economies of these countries. Table 2, below, contains the 2019 ranking. 

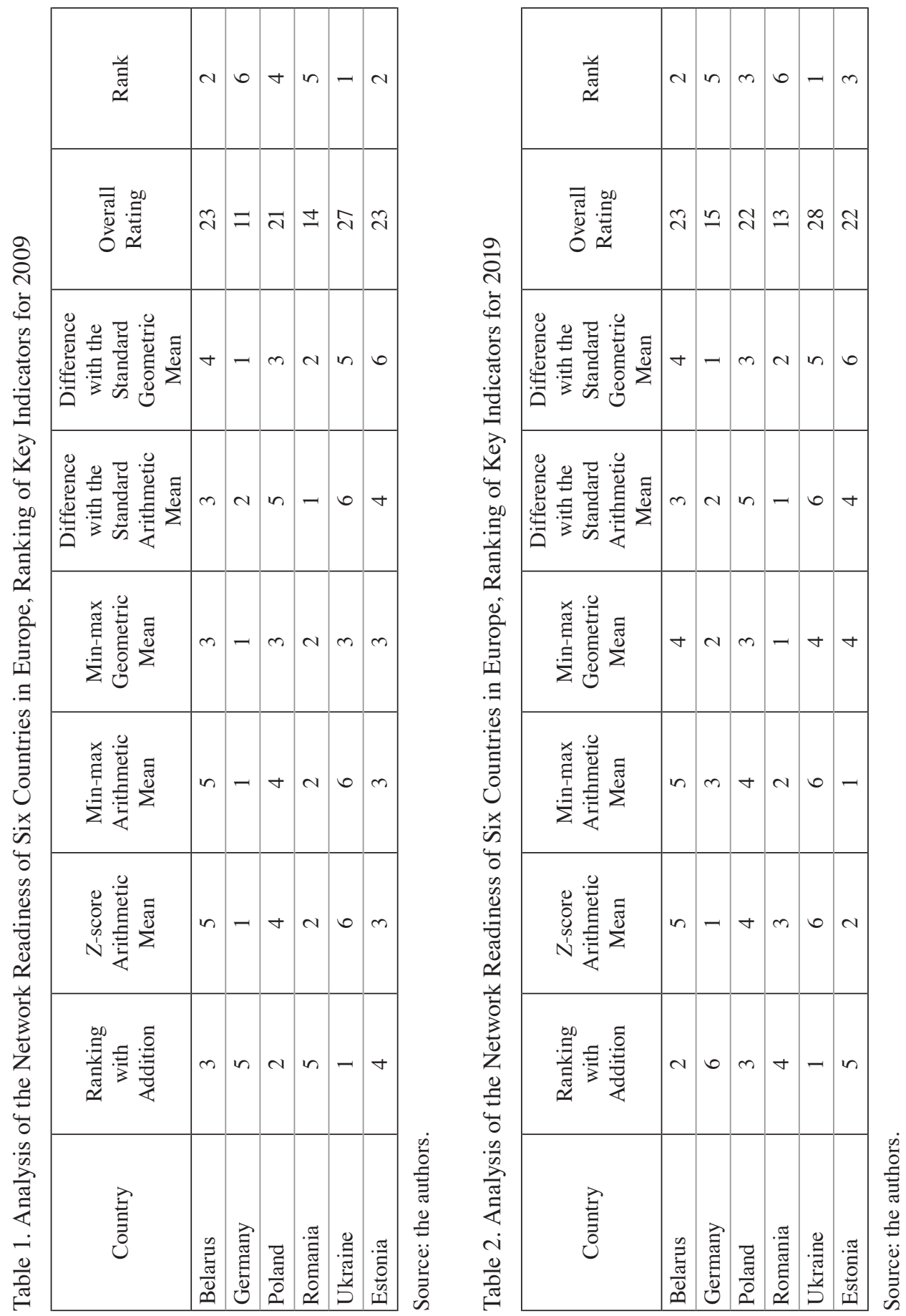
In 2019, Ukraine and Belarus remained unchanged in the rating, but Romania and Estonia improved their positions significantly. In Romania's case, the rise can be attributed to the country's application of the medium-term budget planning in 2008, which led to a decrease in government debt and GDP growth.

The global ICT development index shows results similar to those attained in this study (Fig. 2). The Global ICT Development Index (IDI), calculated by the United Nations global telecommunications agency, the International Telecommunication Union (ITU), is a complex index that determines the ranking of countries using infrastructure of information technology indicators. It has 11 indicators that make up one control value on a scale from 0 to 10 . The IDI index monitors national development of IT and countries' positioning in the global IT market using three sub-indices: access, use and skills. The index ranks countries on indicators of development, implementation and use of IT.

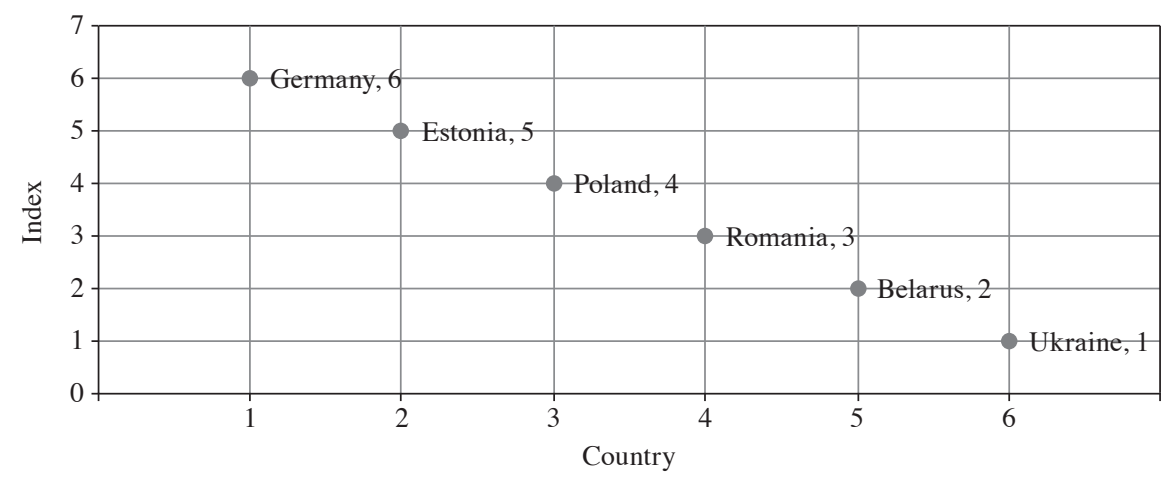

Fig. 2. Ranking of Countries by the Index of Global Inclusion Source: the authors.

In 2020, Belarus and Romania significantly improved their positions, finding themselves among the top ten countries that have dynamically improved their positions since 2015 .

At 79th in the world ranking, Ukraine's low position is primarily due to the poor political and regulatory environment. The factor hindering the development of ICT in our country is the gaps in the judiciary, as evidenced by 139 positions on the assessment of the independence of the judiciary, and 131 - on the ease of appealing against government actions by private business. Ultimately, Ukraine's government lacks a clear plan for introducing and using ICT to increase the country's competitiveness. Table 3 presents two scenarios for the development of digitalisation in Ukraine. 


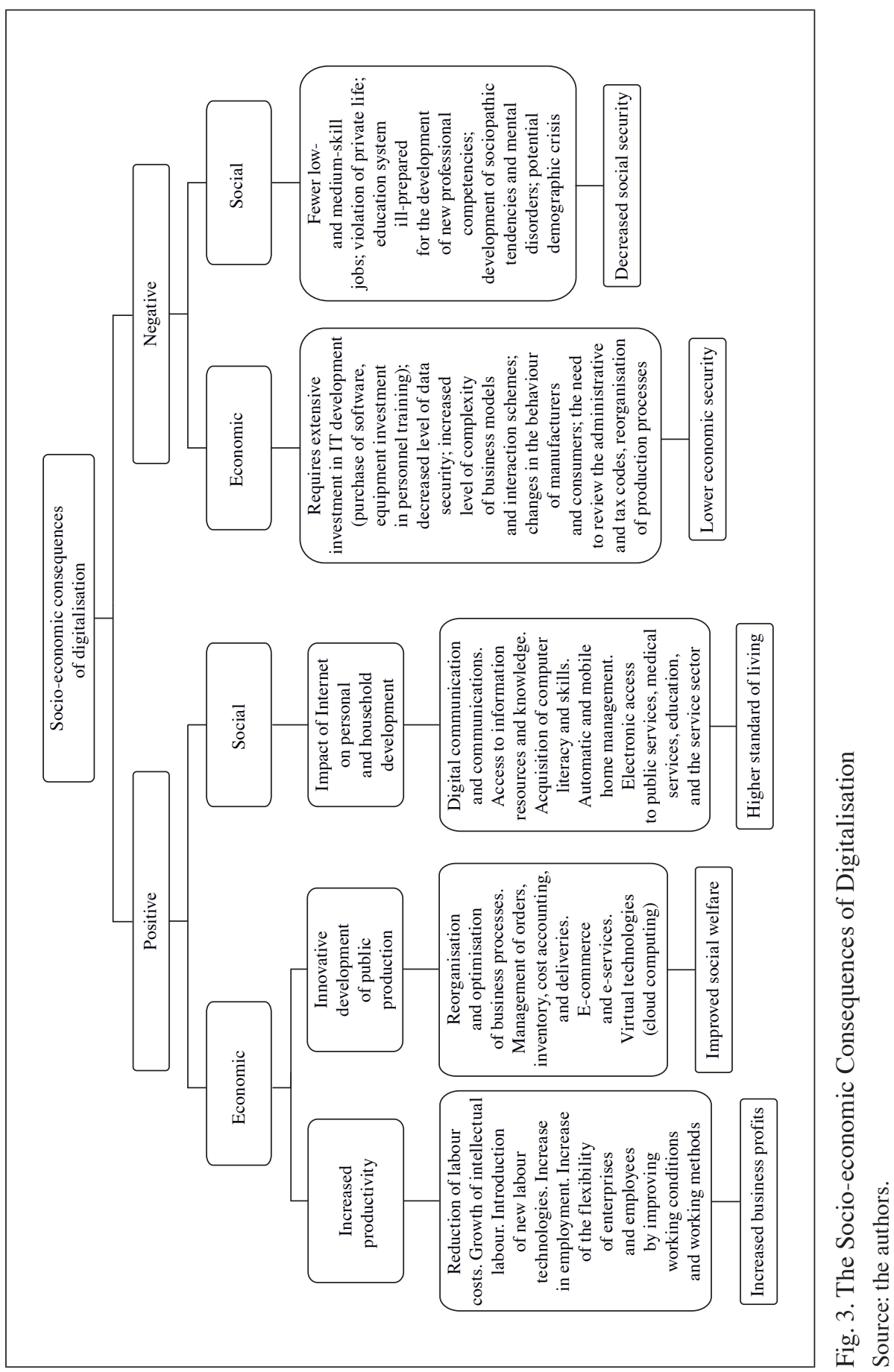


Table 3. Digitalisation Scenarios in Ukraine

\begin{tabular}{|c|c|c|}
\hline $\begin{array}{c}\text { Area } \\
\text { of Development }\end{array}$ & $\begin{array}{c}\text { Scenario } 1 \\
\text { Accelerated Digitalisation }\end{array}$ & $\begin{array}{c}\text { Scenario } 2 \\
\text { Gradual Digitalisation } \\
\text { (Basic Level) }\end{array}$ \\
\hline Perception & $\begin{array}{l}\text { - digital technological progress well- } \\
\text {-received } \\
\text { - exchange culture } \\
\text { - small value of data protection }\end{array}$ & $\begin{array}{l}\text { - critical perception } \\
\text { - high-risk awareness } \\
\text { - intensive data protection }\end{array}$ \\
\hline Education & $\begin{array}{l}\text { - rapid progress in digital teaching and } \\
\text { learning } \\
\text { - expansion of computer science } \\
\text { courses } \\
\text { - communication technologies and data } \\
\text { analysis } \\
\text { - integration of digital skills in many } \\
\text { branches of professional training }\end{array}$ & $\begin{array}{l}\text { - wide range of educational offers } \\
\text { - promotion of creative and } \\
\text { interdisciplinary courses } \\
\text { - slow expansion of digital teaching } \\
\text { methods }\end{array}$ \\
\hline Employment & $\begin{array}{l}\text { - more profound division of labour into } \\
\text { simple and higher specialisation for } \\
\text { qualified workforce } \\
\text { - promotion of retraining and further } \\
\text { training } \\
\text { - progressive flexible mobilisation of } \\
\text { labour relations } \\
\text { - social protection of the self-employed } \\
\text { - use of digital methods for professional } \\
\text { integration of people with disabilities }\end{array}$ & $\begin{array}{l}\text { - expansion of digital activity profiles } \\
\text { - technology supports expansion } \\
\text { of positions in the workplace } \\
\text { - rationalisation of routine activities } \\
\text { - labour relations display limited } \\
\text { flexibility }\end{array}$ \\
\hline Competition & $\begin{array}{l}\text { - accelerated access to digital markets } \\
\text { - weak protection of competition in the } \\
\text { "analog" markets } \\
\text { - domination of models with open } \\
\text { source } \\
\text { - weak copyright protection }\end{array}$ & $\begin{array}{l}\text { - markets at stake protected from } \\
\text { digital competition as much as } \\
\text { possible } \\
\text { - copyright and patent protection } \\
\text { strengthened }\end{array}$ \\
\hline Industry 4.0 & $\begin{array}{l}\text { - technological leadership in the } \\
\text { production of capital goods leads to } \\
\text { high investment in R\&D } \\
\text { - recruitment of IT experts worldwide }\end{array}$ & $\begin{array}{l}\text { - adaptation of digital concepts } \\
\text { - specialisation in industrial services }\end{array}$ \\
\hline Business services & $\begin{array}{l}\text { - strong investment in software and big } \\
\text { data analysis: increased demand due } \\
\text { to industry } 4.0, \text { motor transport, } \\
\text { digital media, and administrative } \\
\text { rationalisation }\end{array}$ & $\begin{array}{l}\text { - transition to technical, economic } \\
\text { and research councils continues, } \\
\text { primarily in creative and artistic } \\
\text { spheres }\end{array}$ \\
\hline Trade & $\begin{array}{l}\text { - extending trading platforms into } \\
\text { consumer and service platforms } \\
\text { - growing number of suppliers } \\
\text { - concentration on multiple platforms } \\
\text { - platforms sell their own products } \\
\text { - more direct marketing from } \\
\text { manufacturers }\end{array}$ & $\begin{array}{l}\text { - cautious acceptance of online trading } \\
\text { - protection of trade and crafts } \\
\text { - expansion of shopping centers } \\
\text { - spatial presence remains important }\end{array}$ \\
\hline
\end{tabular}


Table 3 cnt'd

\begin{tabular}{|c|c|c|}
\hline $\begin{array}{c}\text { Area } \\
\text { of Development }\end{array}$ & $\begin{array}{c}\text { Scenario } 1 \\
\text { Accelerated Digitalisation }\end{array}$ & $\begin{array}{c}\text { Scenario } 2 \\
\text { Gradual Digitalisation } \\
\text { (Basic Level) }\end{array}$ \\
\hline Transport & $\begin{array}{l}\text { - roadworks that manage vehicles will } \\
\text { become standard by } 2030 \\
\text { - car exchange will continue with fully } \\
\text { automated parking } \\
\text { - traffic management systems will } \\
\text { optimise the traffic flow }\end{array}$ & $\begin{array}{l}\text { - the great advantage of self-driving } \\
\text { cars } \\
\text { - the use of such vehicles remains } \\
\text { limited (traffic lanes, trains, busy } \\
\text { roads) }\end{array}$ \\
\hline Mass media & $\begin{array}{l}\text { - radio and television are turning } \\
\text { into entertainment and information } \\
\text { platforms } \\
\text { - focus on multiple platforms } \\
\text { - many information providers (blog } \\
\text { journalists, authors, artists) } \\
\text { - print media declining due } \\
\text { to insufficient circulation }\end{array}$ & $\begin{array}{l}\text { - the advantage of printed products } \\
\text { remains important for the language } \\
\text { and cultural orientation of the media }\end{array}$ \\
\hline Finance & $\begin{array}{l}\text { - rapid expansion of online banking } \\
\text { - virtual currency becoming } \\
\text { increasingly important } \\
\text { - back-office operations outsourced to } \\
\text { specialised suppliers } \\
\text { - focus on investment banking, } \\
\text { corporate business and a large volume } \\
\text { of individual business }\end{array}$ & $\begin{array}{l}\text { - customer preference for individual } \\
\text { support and small regional providers } \\
\text { - online banking is gaining ground } \\
\text { very slowly due to persistent security } \\
\text { issues }\end{array}$ \\
\hline $\begin{array}{l}\text { Personal services } \\
\text { / medicine }\end{array}$ & $\begin{array}{l}\text { - intermediary services via information } \\
\text { platforms } \\
\text { - increasing intensity of social service } \\
\text { technologies } \\
\text { - digital medical technology is highly } \\
\text { developed } \\
\text { - domestic robots and digital home } \\
\text { technologies widely used }\end{array}$ & $\begin{array}{l}\text { - households prefer social services } \\
\text { to personal services } \\
\text { - low acceptance of home robots } \\
\text { - the use of digital medical technologies } \\
\text { slowed by data protection issues }\end{array}$ \\
\hline Public sector & $\begin{array}{l}\text { - digital technologies strongly } \\
\text { promoted } \\
\text { - forced expansion of digital networks } \\
\text { - internet administration of digital } \\
\text { traffic management systems }\end{array}$ & $\begin{array}{l}\text { - technology policy focuses on core } \\
\text { technological competencies and } \\
\text { adaptation of digital technology } \\
\text { diversification } \\
\text { - careful expansion of networks } \\
\text { - careful shift to internet administration }\end{array}$ \\
\hline $\begin{array}{l}\text { Information } \\
\text { technology } \\
\text { industry }\end{array}$ & $\begin{array}{l}\text { - strong growth momentum from } \\
\text { technological changes } \\
\text { - high specialisation in production } \\
\text { control, logistics, network } \\
\text { technologies } \\
\text { - high technological R\&D costs } \\
\text { - domestic producers seeking } \\
\text { to become top IT providers }\end{array}$ & $\begin{array}{l}\text { - growth remains slow } \\
\text { - specialisation as a provider of services } \\
\text { of adaption of mainly foreign IT } \\
\text { products } \\
\text { - growth of the IT security industry } \\
\text { - rising imports of IT research focus on } \\
\text { basic research } \\
\text { - low-level specialisation }\end{array}$ \\
\hline
\end{tabular}

Source: the authors. 
Digital technologies have proven their great potential in numerous fields of social security, including healthcare, workplace safety, fee collection and data exchange. They make it easier to help people in need, such as the elderly with reduced mobility or people with disabilities. They also improve service quality and the integrity of business processes, while reducing operating costs. As a key component of the Digital Revolution, digital platforms are expanding rapidly due to their scalability, flexibility and adaptability. On the one hand, digital platforms create new demands and new opportunities, instantly matching supply and demand with low cost. On the other, they transform the labour market, challenging traditional forms of labour and fragmenting the labour force. This has made lifelong learning and other innovative training programmes indispensable in avoiding large-scale job displacement, possibly caused by automation and robotics, and equipping current and future generations of workers with the necessary skills. After all, if data is a vital part of the digital economy, it is likewise a crucial component of social security. As a part of their activities, social protection agencies accumulate a huge amount of personal data of participants and beneficiaries in order to provide services with extra value, improve the design of programming and even predict the benefits that may be needed in the future. Therefore, they have to make sure that this additional convenience outweighs the risk of misuse of the data collected. In this balance, it is important that the benefit to the individual is clearly greater than the risk.

In order to ensure an effective and timely response to these challenges, social security agencies must adapt to meet new needs and reduce the two main risks: the increasing finance gaps and the disappearing funding base. IASB has identified six priority areas of action:

- legal certainty and harmonisation of the employment status of platform employees,

- ensuring sustainable financing of social security systems,

- data protection,

- people-oriented coordination,

- long-term development of human capital,

- building appropriate information policy.

Paradoxically, however, many citizens and recipients of social services do not use electronic services. That is why it is important to study the role of the information space in modern society and public policy. This role consists in the ability of the information space to display and subsequently change social processes (including political processes), as well as the interests of those who dominate the political process. The most important factor characterising the information space is that not every kind of information can serve as the basis of its structure. Here we are talking only about social information (as opposed to statistical, semantic or 
combinatorial information), since it is social information that is directly related to the comprehension and interpretation of data and the formation of messages with an understanding of what is contained in them. But even social information itself may not be of social significance if it is not communicated to any consumer.

In terms of content, the information space is not just a mechanical sum of resources and the means by which they are processed, but also a configuration of the relations of various public entities to these resources and means. In other words, all the information that enters the information space is a reflection of the information that already takes place in the social space. Each sphere of public life has its own reflection, its own segment in the information space. It is important that its segments are not identical to the similar segments of the social space, just as social and information processes are not identical and do not coincide. Subsystems of the information space include: the media, readers, editorial organisations and the information product they create and distribute. The information space can function effectively only when the media system is complete.

Integrity will be ensured when the following occur: first, various social forces have equal opportunities (within the framework of the law) to access the information space and spread their views in society; second, mass media work to strengthen and expand information relations; third, the information process provides a wide range of opprtunities for any citizen, social group, or state institution to become involved in the spiritual potential of society on a permanent basis; and fourth, information security is guaranteed to the individual, society and state in the information space.

For political science, the second circumstance is of much greater interest, since the connection with the real social space determines the content of the information space to a greater extent than the technical parameters of information systems.

The connection is determined by social processes (including political processes), as well as the interests of the people that dominate the political process. The information space is to a certain extent independent of the social space. This independence manifests itself in the appearance of subjects that act only in the information space and have their main interests in it.

The formation of modern society's information space begins with informatisation, the main goal of which is to fully satisfy the information needs of individuals, society and the state in all spheres of activity, improve living conditions of the population and the efficiency of social production, and help stabilise socio-political relations in the state through the introduction of computer technology and telecommunications.

The main problem of information policy within the framework of the technical and communication approach concerns the development of communication tools. At the same time, the development of technical communication is a priority. 
Within the framework of the state approach, a number of scientists have defined information policy exclusively as the prerogative of the state. Within the framework of the social approach, meanwhile, information policy is understood as a set of goals and methods for achieving sustainable development of the information sphere of society and the state or national interests in the information sphere. In other words, it is understood as certain regulatory actions in the information sphere of public life only.

The research considers information policy as a set of targeted measures of public authorities, implemented in cooperation with other political institutions, elements of civil society and other social subjects with the aim developing personnel, developing and regulating society through media and developing and regulating the information and technical spheres of society and the state.

The main functions of information policy are the following six:

1) to stimulate the harmonious development of the individual, society and the state by means of information;

2) to regulate public relations by means of information;

3) to regulate relations between individuals, society and the state by means of information;

4) to simplify and facilitate information relations between the individual, society and the state;

5) to provide objective information about the state and development of society for individuals, the public and public authorities;

6) to create the greatest opportunities for individuals, society and the state to act effectively in the information space.

\section{Conclusions and Suggestions}

In this article we have analysed the economic and social development of six European states, taking into account the implementation of digitalisation while employing medium-term budget planning. For this we use a ranking method and display the change in the rank of the states in 2019 vs 2009 by selecting the following indicators: GDP at current prices, GDP per capita at current prices, unemployment, national income, total expenditure of public administration, and the network readiness index.

Thus, the research makes it possible to draw conclusions about the need to create conditions for digitalisation of the various states in question. In fact, digitalisation promotes both economic and social growth. The ability to use digital resources has proven effective at the current stage of the crisis caused by the 
COVID-19 pandemic: from the ability to communicate with relatives and social services, purchase necessary goods and medicine to full-fledged work at home.

Key digital trends, as of 2019-2020:

- data have become the main source of competitiveness,

- development of the Internet of Things,

- digital transformations of both individual businesses and entire sectors,

- the emergence of the sharing economy,

- virtualisation of physical infrastructure IT-systems,

- artificial intelligence.

Based on this research, we will construct two scenarios - accelerated digitisation and gradual digitisation - for the development of digitalisation in Ukraine. If the digitalisation is gradual, the Ukrainian economy will remain inefficient, labour migration and brain drain will continue, and Ukrainian products will be less competitive in foreign markets. Ukraine will remain in the backyard of civilisation. Accelerated digitisation, on the other hand, envisages the transition of the Ukrainian economy to a digital one in 3-5 years. This would catapult 2030 Ukraine into a European leader in the fields of innovation and new technologies by 2030, making it an intellectual hub, while creating the most attractive conditions in the region for the development of human potential.

The analysis of the selected countries shows the connection between the development of digital technologies and socio-economic development. It should also encourage further scientific research on the topic.

\section{References}

Ackoff R. (1974), Redesigning the Future, John Wiley \& Sons, New York.

Alonso A. M. (2005), Sovereignty, the Spatial Politics of Security, and Gender: Looking North and South from the US-Mexico Border (in:) State Formation: Anthropological Perspectives, eds Ch. Krohn-Hansen, K. G. Nustad, Pluto Press, London, Ann Arbor, MI. Ansoff H. (1998), How Will Strategic Management Matter in the 21st Century, Paper presented at the Academy of Management Annual Meeting, San Diego, CA.

Ansoff H., McDonnell E. (1990), Implanting Strategic Management, Prentice-Hall, New York.

Azmuk N. (2014), Factors of Formation and Development of Innovative Forms of Human Capital, "Ukraine: Aspects of Work", no 3.

Barkey K., Parikh S. (1991), Comparative State Perspective, "Annual Review of Sociology", vol. 7, no 1, https://doi.org/10.1146/annurev.so.17.080191.002515.

Blishchuk K., Krupnyk A., Matviishin E. (2014), Territorial Development Forecasting. Benchmarking, Kyiv.

Breen K. (2016), What Is "Networked Readiness" and Why Does It Matter?, Weforum, https://www.weforum.org/agenda/2016/07/what-is-networked-readinessand-why-doesit-matter/ (accessed: March 2020). 
Burawoy M. (1990), Marxism as Science: Historical Challenges and Theoretical Growth, “American Sociological Review", vol. 55, no 6, https://doi.org/10.2307/2095745.

Drucker P. F. (2002), Managing in the Next Society, Truman Talley Books/ St. Martin's Griffin, New York.

Glushchenko A., Kucherova E. P. (2016), Methodics of Forming the Policy of Reporting for an Agricultural Holding's Segmental Reporting, "Management Reporting", no 1.

Gray A. (1948), Adam Smith, George Philip \& Son, London.

Gudz P., Gudz M. (2019), Inclusive Development of the Region's Economy: The Challenges of Globalization and the Possibility of Regionalization, "Roczniki Ekonomiczne Kujawsko-Pomorskiej Szkoły Wyższej w Bydgoszczy”, no 12.

International Labour Office (2018), World Employment and Social Outlook: Trends 2018, ILO, Geneva, https://www.ilo.org/wcmsp5/groups/public/---dgreports/---dcomm/--publ/documents/publication/wcms_615594.pdf (accessed: December 2020).

International Telecommunication Union (2017), Measuring the Information Society Report 2017. ICT Country Profiles: ITU, vol. 2, Geneva.

Korol S. (2019), Digitalization of the Economy as a Factor of Professional Development, "Modern Economics", no 18, https://217.77.213.157:8080/jspui/bitstream/123456789/ 6619/1/korol.pdf (accessed: December 2020).

Kovtonyuk K. (2017), Digitization of the World Economy as a Factor of Economic Growth, "Scientific Bulletin of Kherson State University", vol. 27, no 1.

Kraus N., Kraus K. M. (2018), Digitalization in the Context of the Institutional Transformation of the Economy: The Basic Components and Tools of Digital Technologies, "Intelect XXI stolittia", no 1.

Kulynych M. (2019), Digital Economy Trends in the Global Economic Space, "Modern Economics", vol. 16, no 1, https://doi.org/10.31521/modecon.v16(2019)-08.

Laitsou E., Kargas A., Varoutas D. (2020), Digital Competitiveness in the European Union Era: The Greek Case, "Economies", vol. 8, no 4, https://doi.org/10.3390/ economies 8040085.

Lipsey R. G., Chrystal A. (2015), Economics, Oxford University Press, Oxford.

Nagy S. (2017), Digital Economy and Society - A Cross Country Comparison of Hungary and Ukraine, "Visnyk natsionalnogo tekhichnogo universytetu kharkivskyj politekhnichnyj instytut ekonomichni nauky", vol. 46, no 1267.

Portulans Institute (2019a), Network Readiness Index 2019, https://networkreadinessindex. org/wp-content/uploads/2019/12/The-Network-Readiness-Index-2019_Full_draft-V2. pdf (accessed: February 2020).

Portulans Institute (2019b), Network Readiness Index 2019 Analysis. World Information Technology and Services Alliance, https://networkreadinessindex.org/nri-2019analysis/\#renewed-model (accessed: March 2020).

Portulans Institute (2019c), Network Readiness Index 2019 Analysis. 2019 Highlights, https://networkreadinessindex.org/2019/\#countries (accessed: March 2020).

Schwab K. (2016), World Economic Forum, Geneva.

Sergienko I. V., Mikhalevich M. V., Stetsyuk P., Koshlai L. B. (2009), Models and Information Technologies for Decision Support during Structural and Technological Changes, "Cybernetics and Systems Analysis", vol. 45, no 2, https://doi.org/10.1007/ s10559-009-9091-7.

Silja B., Soumitra D., Bruno L. (2017), The Global Information Technology Report 2016: Innovating in the Digital Economy, Cornell University, INSEAD, WEF, Geneva. 
State Statistics Service of Ukraine (2019), Gross Domestic Product, https://ukrstat.gov.ua/ (accessed: January 2020).

Toffler A. (1980), The Third Wave, W. Morrow, New York.

Trushlyakova A. (2018), Development of Digitalization in Ukraine: Factors of Influence, Advantages and Challenges of Today, "Economic Horizons", vol. 4, no 7.

Veerpalu V., Pastukh S., Volodina E., Devyatkin E. (2014), Features and Prospects of Development of Broadband Access in the USA, "Elektrosviaz", no 10.

Veretyuk S., Pilinskiy V. (2016), Viznachennya prioritetnih napryamkiv rozvitku tsifrovoyi ekonomiki v Ukrayini [Determination of Priority Directions of Development of Digital Economy in Ukraine], Naukovi zapiski Ukrayinskogo naukovo-doslidnogo Institutu zv'yazku [Scientific Notes from the Ukrainian Telecommunication Research Institute].

Voitko S. (2019), Conception of Industry 4.0. in the Sustainable Grown of Ukraine, Creative Business for Smart and Sustainable Crowth, CreBUS.

Voronin A., Kizim N. (2006), Model of the Production Cycle, "Biznes Inform", vol. 6.

World Economic Forum (2009-2016), Networked Readiness Index, https://reports. weforum.org (accessed: January 2020).

Zelisko I. M. (2012), The Innovative Imperatives of Development of Integration Agroindustrial Formation, "Scientific Bulletin of Lviv National University of Veterinary Medicine and Biotechnology named after S. Z. Gzhytskyj”, vol. 14, no 1(51).

\section{Cyfryzacja gospodarki jako czynnik zwiększania konkurencyjności państwa} (Streszczenie)

Cel: Celem artykułu jest rozważenie głównych wyzwań i korzyści płynących z cyfryzacji ukraińskiej gospodarki, a także wskazanie, jakie zagrożenia i ryzyko niesie ze sobą ten proces, oraz opracowanie narzędzi i planów transformacji cyfrowej do oceny poziomu gospodarki cyfrowej na Ukrainie.

Metodyka badań: Przeprowadzono retrospektywną analizę rozwoju gospodarczego i społecznego wybranych państw, biorąc pod uwagę wdrażanie cyfryzacji i wykorzystanie średniookresowego planowania budżetowego. W tym celu posłużono się metodą rankingową i przestawiono zmianę miejsca w rankingu państw w 2019 r. w porównaniu z 2009 r., uwzględniając następujące wskaźniki: produkt krajowy brutto w cenach bieżących, produkt krajowy brutto na mieszkańca w cenach bieżących, bezrobocie, dochód narodowy, wydatki ogółem administracji publicznej oraz sieciowy wskaźnik gotowości.

Wyniki badań: Badania pozwalają na wyciągnięcie wniosków dotyczących potrzeby stworzenia warunków do cyfryzacji Ukrainy. Umiejętne korzystanie z zasobów cyfrowych potwierdziło swoją skuteczność w okresie kryzysu wywołanego pandemią COVID-19. Autorzy ocenili efekt makroekonomiczny, biorąc pod uwagę wpływ inwestycji w technologie cyfrowe i infrastrukturę cyfrową na PKB, a także uwzględniając wzrost produktywności poprzez cyfryzację. Według szacunków podanych w artykule udział gospodarki cyfrowej w PKB największych krajów świata w 2030 r. wyniesie 50-60\%. Na Ukrainie 
wartość ta, według obliczeń autorów, może być jeszcze wyższa i wynieść 65\% PKB (gdyby zrealizowany został proponowany scenariusz gospodarki cyfrowej na Ukrainie). Wnioski: Na podstawie przeprowadzonych badań skonstruowano dwa scenariusze rozwoju cyfryzacji na Ukrainie: scenariusz 1 - przyspieszona cyfryzacja, scenariusz 2 - stopniowa cyfryzacja. W przypadku realizacji scenariusza 2 ukraińska gospodarka pozostanie nieefektywna, migracja zarobkowa i drenaż mózgów będą kontynuowane, a ukraińskie produkty stracą konkurencyjną pozycję na rynkach zagranicznych. Ukraina pozostanie na marginesie cywilizacji. Scenariusz 1 przewiduje przejście ukraińskiej gospodarki na cyfrową za 3-5 lat. W wyniku realizacji tego scenariusza Ukraina do 2030 r. stanie się europejskim liderem w dziedzinie innowacji oraz nowych technologii i centrum intelektualnym.

Wkład w rozwój dyscypliny: Przeprowadzone przez autorów badania pozwolą wyznaczyć główne kierunki rozwoju cyfryzacji gospodarki Ukrainy na podstawie doświadczeń europejskich, a zaproponowane scenariusze rozwoju pomogą stworzyć w regionie najatrakcyjniejsze warunki do rozwoju potencjału ludzkiego.

Słowa kluczowe: gospodarka cyfrowa, cyfryzacja, usługi cyfrowe, technologie cyfrowe, technologie informacyjne i komunikacyjne, państwo, społeczeństwo. 